centres are well equipped and staffed, and have met with undoubted success since their inception in 1960.

Mr Sneed says that the scale of Japanese education should not be underestimated. In 1966 there were 346 four-year universities, of which 111 were operated by the state. More than 70 per cent of Japanese children stay on at school until or past the age of 18 , and 11 per cent receive a university education. In England, 7.3 per cent of boys and 3.2 per cent of girls go to university; these figures, however, are not of course strictly comparable.

In the United States Mr Sneed says he has investigated the Engineering Concepts Curriculum Project (ECCP), a scheme which calls for the development of an introductory course in engineering and the training of teachers to conduct it. The aim is not specifically to attract students to a career in engineering but, like the industrial arts course in Japan, to provide an understanding of the technical background of modern life. There are signs that the popularity of engineering as a career in the United States is decreasing and, although it is too early yet to evaluate the course developed by the ECCP, its progress will be watched with interest.

\section{Education for Engineers}

Plans to bring the United States Commission on Engineering Education into the structure of the National Academy of Engineering were announced in Washington DC last week. The commission was founded by the National Science Foundation in 1962 to meet the needs for improving undergraduate education in engineering. It is supported by the NSF and by private means. Since 1962, the work has covered areas such as the educational aspects of computers, manpower requirements for engineers in specifie fields, the development of an Engineering Concepts Curriculum Project for high schools and the development of undergraduate engineering laboratories.

The reason for the proposed association is that the commission recognized a need to establish "a more substantial basis of operation than that provided by its independent status". According to Dr Eric A. Walker, president of the National Academy of Engineering, it is hoped that this relationship will encourage new ideas and new programmes as well as establishing co-operation with other organizations dealing with engineering education. Formal dissolution of the commission as a corporation will take place no later than March 1, 1969. Meanwhile, the commission will continue to administer existing programmes, and new projects will be handled by the Committee on Engineering Education within the academy.

\section{Some Steam Ahead}

THe award to a British company of a contract for a large turbine generator for Consolidated Edison in New York is a considerable coup at any time. To beat General Electric and Westinghouse, and the highly effective Swiss company Brown Boveri, adds savour to the triumph. But there must be some long faces in Associated Electrical Industries just the same. If the order had come only two months ago, it might have been decisive in turning away the bid with which
Mr Arnold Weinstock of the General Electric Company took over AEI. Naturally AEI is trying very hard to play down the issue, despite its jubilation at winning the order. Mr Weinstock, for his part, must be gratified that the turbine division of his new empire is already giving evidence of its competitiveness-it could mean one less problem for him, and keep alive hopes of maintaining the division through a difficult period. The Central Electricity Generating Board is now cutting back so hard on new orders-despite the recent cold spell, it still had substantial spare capacity- that there is little hope of selling generating capacity in Britain for the next two years or so. Export orders are therefore more than just an encouragement-they are a lifesaver.

The contract which AEI has won is for one turbine generator with auxiliary equipment, worth $£ 10$ million; but it is more than likely that an order for another similar unit will be forthcoming. Placing contracts in this way is a common practice in the United States, and AEI is confident of winning the option. The generator is of unprecedented size for a British company-1,100 MW from a single shaft, against the 660 MW units which the CEGB has reached. The unit will be run from a boiling light water reactor, and will be a relatively low pressure, low temperature unit, running at $1,800 \mathrm{rpm}$. These units are different from the ones the CEGB uses, which use a higher grade steam.

Because the steam from the reactor will be saturated with water, and partially decomposed into hydrogen and oxygen, there are particular corrosion and erosion problems on the turbine blades. The amount of erosion depends on the tip speed of the turbine blades, so it pays to keep this as low as possible. AEI has managed to do this by using a device developed by one of its engineers-the Baumann multi-exhaust. Although the other tenders for the Con Ed contract specified a blade size of 52 inches for the final set of blades, AEI says that its blades are much smaller. The generator will use a combination of cooling techniques. The stator will be water cooled, by a design which AEI itself developed. But, although there had been speculation that the rotor would also have to be water cooled on a unit this size, AEI have provided hydrogen cooling. This is not because it is technically impossible to cool the rotor with waterAEI is convinced that it knows how to do it-but merely because it might provide a weak link in the design. Cooling by hydrogen gas is well proved, so AEI has decided to use it.

The set will also be provided with a series of water separators, designed to remove as much water as possible from the steam. In the design of these, AEI will be calling on the experience gained in the contract for the turbines for the steam generating heavy water reactor at Winfrith Heath in Dorset. Although the SGHWR is very much smaller than the Con Ed contract, it shares some of the problems.

\section{The Lunar Society}

$$
\text { from D. G. Kin o-Hele }
$$

THE informal but influential meetings of the Lunar Society of Birmingham began about the year 1766, and its 200th anniversary was commemorated in 